\title{
9. PETROLOGY OF UPPER JURASSIC-LOWER CRETACEOUS LIMESTONES, DSDP SITE 391
}

\author{
Tom Freeman, Department of Geology, University of Missouri, Columbia, Missouri \\ and \\ Paul Enos, Department of Geological Sciences, State University of New York, Binghamton
}

\section{INTRODUCTION}

Site 391 of DSDP Leg 44, within the Blake-Bahama Basin (Figure 1), was chosen to sample a thick sedimentary section that probably includes the oldest sedimentary rocks (Lower Jurassic?) in any ocean basin (Figure 2). Drilling at Site 391 failed to reach basement, however, and the record-breaking 1412-meter subbottom depth encountered rocks no older than lower Tithonian (Figure 3). These lower Tithonian limestones and the thicker overlying upper Tithonian-Barremian carbonates are the subject of this report.

The character of the Tithonian-Barremian limestone is much like that of unit 4 of DSDP Leg 11 (Lancelot et al., 1972, p. 921), which was described as white and gray limestone of deep bathyal origin. Drilling at Site 391 did provide one important addition to the sedimentologic features described by earlier works; turbidites were encountered between 1001.3 meters and 1124 meters, in rocks of Hauterivian age (Figure 4). A notable example occurs within a $200-\mathrm{cm}$ interval of Core 391C-17 where we encountered four separate turbidite units, each with one or more of the features diagnostic of turbidites described by Bouma (1962, p. 49-51).

\section{SEDIMENTOLOGY}

Jurassic-Lower Cretaceous rocks drilled at Site 391 are divided into six informal sub-units labeled 4a through $4 \mathrm{~d}$ and $5 \mathrm{a}$ through $5 \mathrm{~b}$ in the Site 391 Report, this volume (Figure 4). The boundary between units 4 and 5 is marked by a change from white and gray, millimeter-laminated limestones above to argillaceous red limestone below. This boundary falls within the Tithonian Stage.

\section{Sub-unit 4a}

The sediments of sub-unit $4 \mathrm{a}$ are calcareous claystone with numerous calcitized ${ }^{1}$ radiolarians (Plate $^{2}$ 1, Figure 1) and sandy limestones. At several levels between depths of 1001.3 and 1124 meters, pelagic calcareous claystone is truncated by layers of sandy calcarenite, the latter reflecting turbidity-current deposition (Plate 1, Figures 2 and 3). The terrigenous fraction of the turbidite layers includes quartz, micro-

\footnotetext{
'We have not accurately assessed the extent to which the radiolarians have been replaced by calcite, as opposed to simple calcite filling their molds.
}

cline, plagioclase, and orthoclase (Plate 2, Figure 1). Polycrystalline quartz (Plate 2, Figure 2) is extremely rare. The source for the terrigenous detritus was apparently a fresh granite.

In contrast, ooids, though abraded (Plate 2, Figure $3)$, are clearly not terrigenous. Furthermore, the associated fossil algae were probably not derived from pre-existing rock (Plate 2, Figure 4). Both the ooids and the fossils reflect a very shallow (photic zone) site of carbonate-sand generation. During the Early Cretaceous, carbonate sands and terrigenous debris were occasionally carried together by turbidity currents to the area of Site 391. The co-occurrence of carbonate grains and terrigenous debris suggests that both were derived from the outer continental shelf to the west, which is known to contain Lower Cretaceous ooids (Site 392 Report, this volume) and terrigenous sands in the inner shelf. Although the Bahama Banks to the south could have been a source for the lime sands, they could not have been a source for the associated terrigenous sands, thus precluding a Bahaman source for the turbidites. (See Paulus, 1972, p. 892 for details of Bahaman Cretaceous stratigraphy.)

Sub-unit 4b

Sub-unit $4 \mathrm{~b}$ consists of (1) light to very dark gray laminated calcilutite, (2) bioturbated calcilutite, (3) black claystone and (4) massive gray calcilutite in apparently random order.

Calcareous nannofossils are abundant in limestones of this unit, but foraminifers are virtually absent, which suggests accumulation below the compensation depth for foraminifer calcite. Poorly oxygenated bottom conditions resulted in partial pyritization of radiolarians and ome dark laminae of the laminated calcareous claystone facies (Plate 2, Figure 6). Certain disturbed laminae (Plate 3, Figure 1) and microfaults (Plate 3, Figure 2) probably resulted from dewatering events.

Laminations in the marly limestone illustrated in Plate 2, Figure 6, are about one millimeter thick and are so evenly spaced that they suggest an origin similar to that of varves. However, close examination of several intervals of typical laminations showed that the millimeter laminae are themselves compound and that they contain an average 67 laminations per $\mathrm{cm}$. On the basis of this spacing of laminations, coupled with the computed sedimentation rate of $2.5 \mathrm{~cm}$ per 1000 years (computed from biostratigraphic data), the length of time recorded by a single lamination is, on the average, 6 years. We cannot easily explain the laminations in 


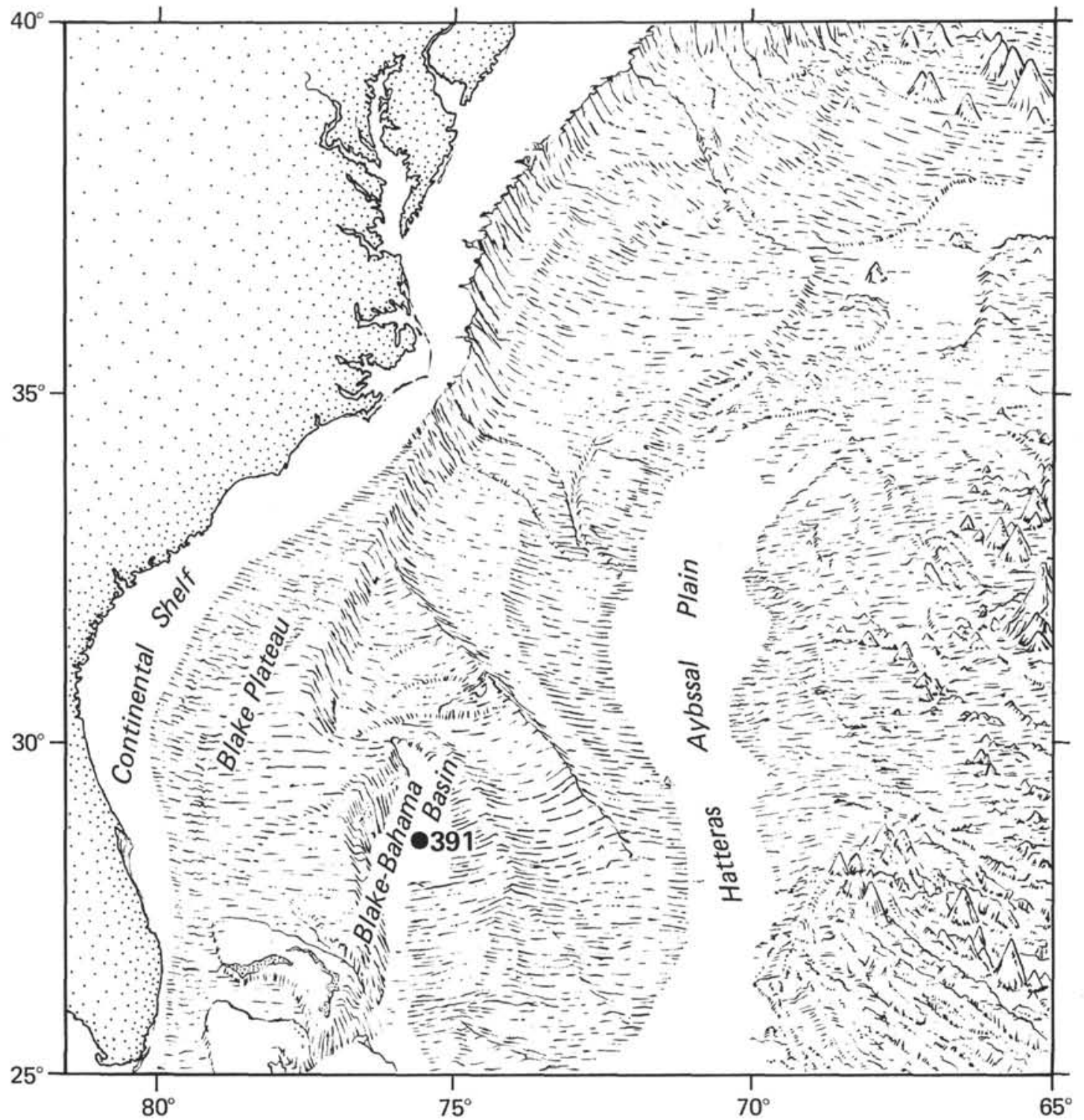

Figure 1. Physiographic diagram of a portion of the western North Atlantic (Heezen and Tharp, 1968 ) with Site 391 shown at $28^{\circ} 13.67^{\prime} \mathrm{N}$ latitude, $75^{\circ} 36.88^{\prime} \mathrm{W}$ longitude.

terms of climatic fluctuations. Still, they appear to be too uniform and too planar to be ascribed to the fluctuations of bottom currents.

\section{Sub-unit 4c}

Sub-unit $4 \mathrm{c}$ is characterized by bioturbated lime mudstone and marly limestone similar to certain intervals in sub-unit $4 \mathrm{~b}$. Wispy and discontinuous laminae (Plate 3, Figure 3) reflect a combination of bioturbation and dewatering processes. Sample 391C$34-4,3-8 \mathrm{~cm}$, has numerous fragments of the alga Thaumatoporella, which are approximately $55 \mu \mathrm{m}$ wide (Plate 3, Figure 4).

\section{Sub-unit 4d}

This sub-unit contains limestone essentially like that of sub-unit $4 c$ except that in $4 d$ there is a more thorough segregation of carbonate and clay (Plate 4, Figure 1). A trace of microcrystalline chert occurs at a sub-bottom depth of 1259 meters, and stylolites occur below a depth of 1270 meters (Plate 4, Figure 2).

\section{Sub-unit 5a}

The limestone of this interval is texturally like the white limestone of sub-unit $4 \mathrm{~d}$, but it differs markedly in color. Marly limestones of sub-unit 5a are pale red (2.5YR6/2), reddish brown $(2.5 Y \mathrm{R} 4 / 4)$, weak red $(2.5 \mathrm{YR} 4 / 2)$, bluish white $(5 \mathrm{~B} 9 / 1)$, and greenish gray (5GY6/1). Textures of the different colored lithologic types are indistinguishable.

\section{Sub-unit 5b}

Sub-unit 5 b is a "red" marl. The average $\mathrm{CaCO}_{3}$ content, on the basis of five Leco analyses (see App. I) is 33 per cent. The color of sub-unit $5 \mathrm{~b}$ is dark reddish brown (5YR 3/2). Shell fragments, possibly clams (one apparently consisting of nacreous aragonite), and several ammonites were found in sub-unit $5 \mathrm{~b}$, along with a possible cross-laminated layer $1 \mathrm{~cm}$ thick. Calcareous 


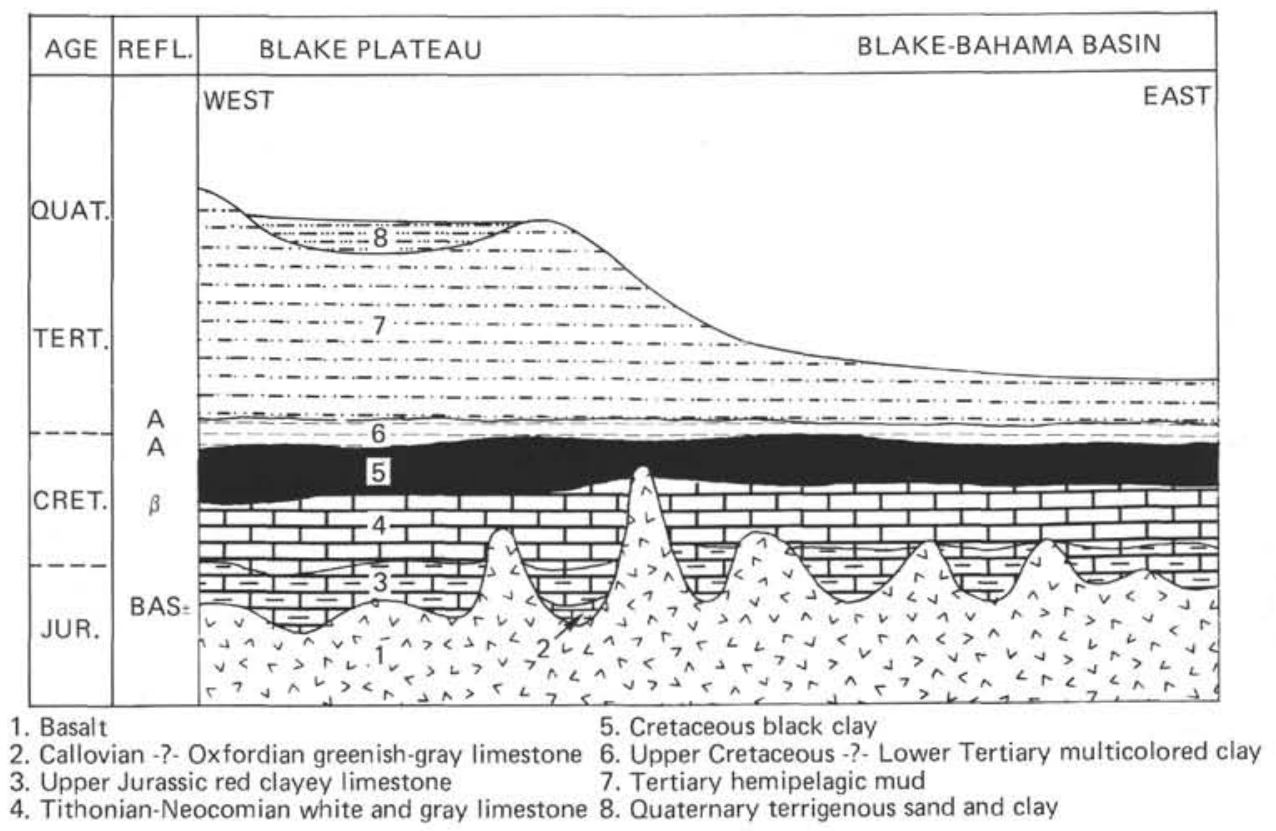

Figure 2. Schematic distribution of the different facies recognized from drilling and seismic profiler records in the area of report (after Lancelot et al., 1972, p. 903). Unit 4 and the uppermost part of unit 3 comprise the interval of this report.

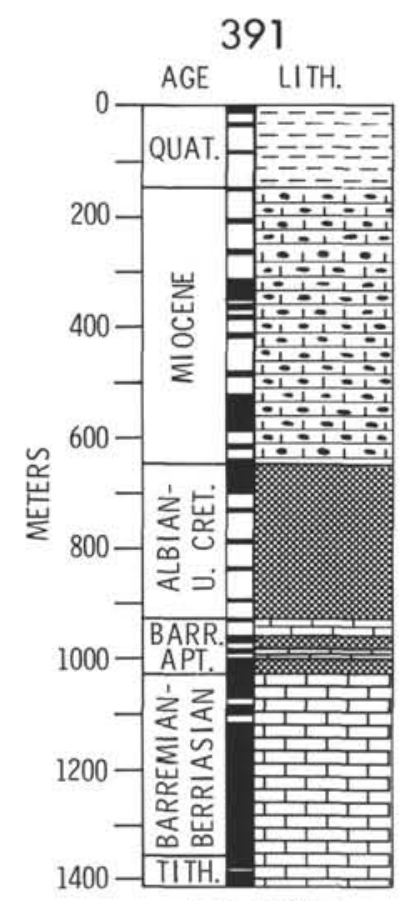

T. D. $=1412 \mathrm{~m}$

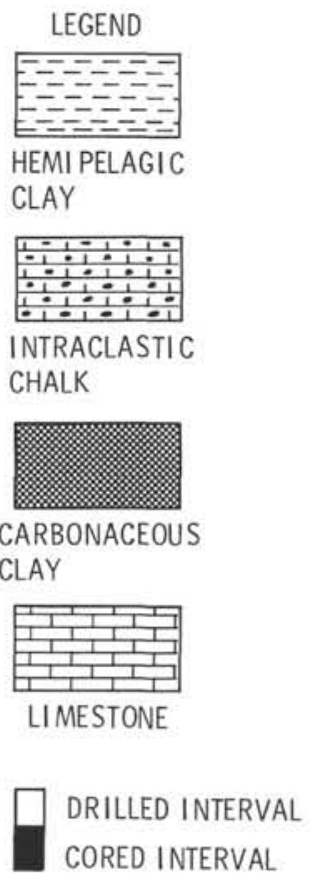

Figure 3. Generalized lithic stratigraphy of Site 391 (after Benson, Sheridan, et al., 1976, p. 25).

nannofossils, which, in smear-slide estimates range up to 30 per cent, presumably account for the bulk of the $\mathrm{CaCO}_{3}$.

Limestones similar to those of sub-units $5 \mathrm{a}$ and $5 \mathrm{~b}$ were recovered on Leg 11 and were equated by Bernoulli (1972, p. 806) with the Ammonitico Rosso facies of Italy. Although the red limestones of unit 5
(Plate 4, Figure 3) are similar in color and texture to those figured by Bernoulli, Jurassic red marlstone from Site 391 lacks the nodular appearance of their European counterparts.

\section{ENVIRONMENTS OF DEPOSITION}

Upper Jurassic-Lower Cretaceous rocks of Site 391 reflect accumulation well above the compensation depth for nannofossils but at or below that for foraminifers, as indicated by (1) the richly calcareous sediments owing in large measure to the numerous nannofossils, and (2) the near absence of foraminifers. In modern oceans this depth occurs between 4.5 and 5.5 $\mathrm{km}$. Bioturbation features are common and show that the ocean floor was well oxygenated during much of the time (Plate 4, Figure 1). Occasional stagnant conditions are reflected by very dark laminae, some of which suggest an enigmatic periodicity (Plate 4, Figure 4).

Several sandy calcarenitic intervals near the top of the Lower Cretaceous mark the abrupt deposition of mixed terrigenous and carbonate sands. These grade upward into the bioturbated nannofossil limestones described earlier. We did not determine rates of accumulation of these turbidite sands because their associated faunas are mixed. The nannofossil limestones, however, calculated on the basis of nannofossil zonation, accumulated at rates ranging from $1.1 \mathrm{~cm}$ to $2.8 \mathrm{~cm}$ per 1000 years.

Some degree of depositional slope is suggested by low-angle microfaults like that in Plate 2, Figure 6, but dewatering processes could also explain such features as well as the steeper microfaults shown in Plate 3, Figure 2. Similar "faults" were reported from Site 105 in the western North Atlantic. 


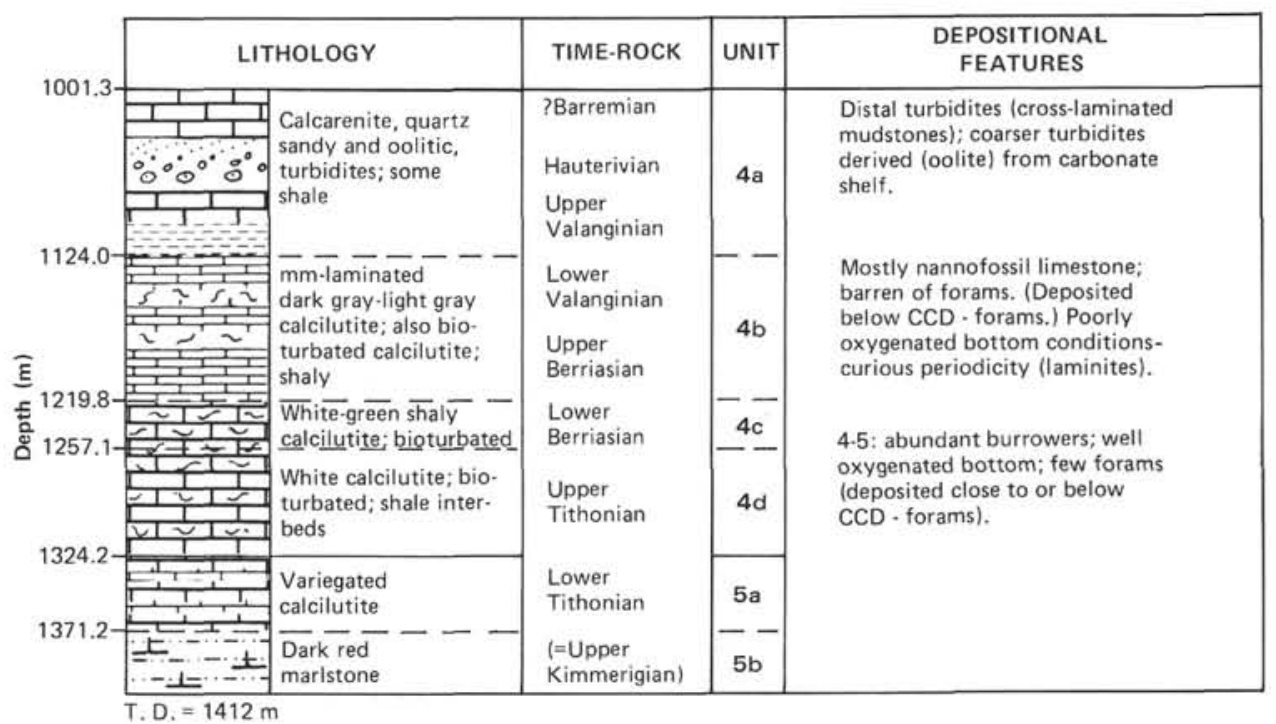

Figure 4. Lithologic summary of Jurassic and lowermost Cretaceous rocks drilled in Hole $391 C$.

\section{DIAGENESIS}

The origin of fine-grained carbonate sediment that comprises the lime matrix of these rocks is uncertain. It may be finely comminuted nannofossil debris, or it may be a fine fraction that was transported seaward from some nearby carbonate bank. Its large areal extent, which has been documented by drilling at DSDP sites more than $1300 \mathrm{~km}$ apart, suggests that it had a pelagic nannofossil source. The near absence of associated foraminifers indicates a lime mud that initially consisted of calcite different from that which occurs in foraminifers. (Aragonite is an unlikely possibility because of its relatively shallow CCD.) In any case, the lime matrix appears to have recrystallized during diagenesis, which, if accompanied by compaction, could have produced lithification of the carbonate sediments. Compaction is definitely indicated by the elliptical shapes of radiolarian molds (Plate 5, Figure 1). Redistribution of $\mathrm{CaCO}_{3}$ is evidenced by sparry calcite cement within radiolarian molds and spicules (Plate 5, Figures 2 and 3), as well as by the replacement of radiolarians by calcite (Plate 5 , Figure 4). In cases where radiolarians have been partially replaced by pyrite, their skeletal architecture is relatively well preserved (Plate 5, Figure 5). In contrast, those radiolarians that have been calcitized (Plate 5, Figure 5) have little or no skeletal structure. This suggests that partial pyritization of radiolarians preceded calcitization.

The sequence of diagenetic events suggested by the foregoing observations follows:

1) Fine-grained carbonate mud of uncertain origin containing abundant nannofossils but few foraminifers accumulated in water depths ranging from 4.5 to 5.5 $\mathrm{km}$. Rates of sediment accumulation ranged from 1.1 to $2.8 \mathrm{~cm}$ per 1000 years. $^{2}$

${ }^{2}$ Calculation of depositional rates is subject to error because of sediment compaction and reduction of section through stylolitization.
2) Radiolarians were slightly pyritized, probably as a result of anaerobic conditions below the sedimentwater interface, shortly after deposition. Bioturbation, which also occurred concomitantly with sedimentation, attests to at least occasional well-oxygenated bottom conditions.

3) Compaction, which probably accompanied the solution and calcite replacement of radiolarians, distorted the radiolarians into ellipsoidal shapes. This distortion of radiolarians was immediately followed by their occlusion with sparry calcite cement, along with general lithification of the sediments. Lithification was probably facilitated by the conversion of calcium carbonate to some more stable form during compaction. The $\mathrm{CaCO}_{3}$ that was mobilized during this phase of diagenesis probably provided the cement for the quantitatively minor turbidite sands as well. We are not certain when in the diagenetic sequence the microcrystalline chert (Plate 5, Figure 6) was formed.

\section{ACKNOWLEDGMENT}

Thanks go to Donald H. Zenger, of Pomona College, for reviewing the manuscript.

\section{REFERENCES}

Benson, W.E., Sheridan, R.E., et al., 1976. In the North Atlantic: deep-sea drilling: Geotimes, v. 21, p. 23-26.

Bernoulli, D., 1972. North Atlantic and Mediterranean Mesozoic facies: A comparison. In Hollister, C.D., Ewing, J.I., et al., 1972. Initial Reports of the Deep Sea Drilling Project, Volume 11: Washington (U.S. Government Printing Office), p. 801-871.

Bouma, A.H., 1962. Sedimentology of some flysch deposits: Amsterdam (Elsevier Pub. Co.).

Heezen, B.C. and Tharp, M., 1968. Physiographic diagram of the North Atlantic Ocean, Boulder (Geol. Soc. Am.).

Lancelot, Y. Hathaway, J.C., and Hollister, C.D., 1972. Lithology of sediments from the western North Atlantic, 
Leg XI, Deep Sea Drilling Project. In Hollister, C.D., Ewing, J.I., et al., Initial Reports of the Deep Sea Drilling Project, Volume 11: Washington (U.S. Government Printing Office), p. 901-949.
Paulus, F.J., 1972. The geology of Site 98 and the Bahama Platform. In Hollister, C.D., Ewing, J.I., et al., Initial Reports of the Deep Sea Drilling Project, Volume 11: Washington (U.S. Government Printing Office), p. $877-$ 897. 


\section{PLATE 1}

Fossiliferous Lime Mudstones and Turbidites From Sub-unit 4a

Figure 1 Photomicrograph of calcitized radiolarians in calcareous claystone. Pyrite partially fills radiolarian at extreme right center. $\times 100$. Sample 391C$14-1,80-87 \mathrm{~cm}$.

Figure 2 Core of sandy calcarenite, cross-laminated at top. Sample 391C-17-2, 122-131 cm.

Figure 3 Core of bioturbated pelagic calcareous claystone (lighter in color in its upper part) abruptly overlain by cross-laminated sandy calcarenite. Sample $391 \mathrm{C}-18-1,135-144 \mathrm{~cm}$.

\section{PLATE 2}

Petrography and Structures of Sub-units $4 a$ and $4 b$

Figure 1 Photomicrograph (cross-polarized light) of turbidite sand from sub-unit $4 \mathrm{a}$ showing quartz, microcline, orthoclase, and plagioclase. $\times 100$. Sample 391C-17-2, 122-135 cm.

Figure 2 Photomicrograph (cross-polarized light) of turbidite sand from sub-unit $4 \mathrm{a}$ showing polycrystalline quartz. $\times 100$. Sample 391C-18-1, 131$150 \mathrm{~cm}$.

Figure 3 Photomicrograph (plane light) of turbidite sand from sub-unit $4 \mathrm{a}$ showing abraded ooid. $\times 100$. Sample $391 \mathrm{C}-17-2,122-135 \mathrm{~cm}$.

Figure 4 Photomicrograph (plane light) of turbidite sand from sub-unit $4 \mathrm{a}$ containing a red alga. $\times 100$. Sample 391C-17-2, 122-135 cm.

Figure 5 Photomicrograph (plane light) of pyritized and calcitized radiolarians in calcareous claystone from sub-unit 4b. $\times 100$. Sample 391C-25-1, 72-86 $\mathrm{cm}$.

Figure 6 Core of millimeter-laminated lime mudstone from sub-unit 4b. Sample 391C-31-3,140-146 cm. 
PLATE 1
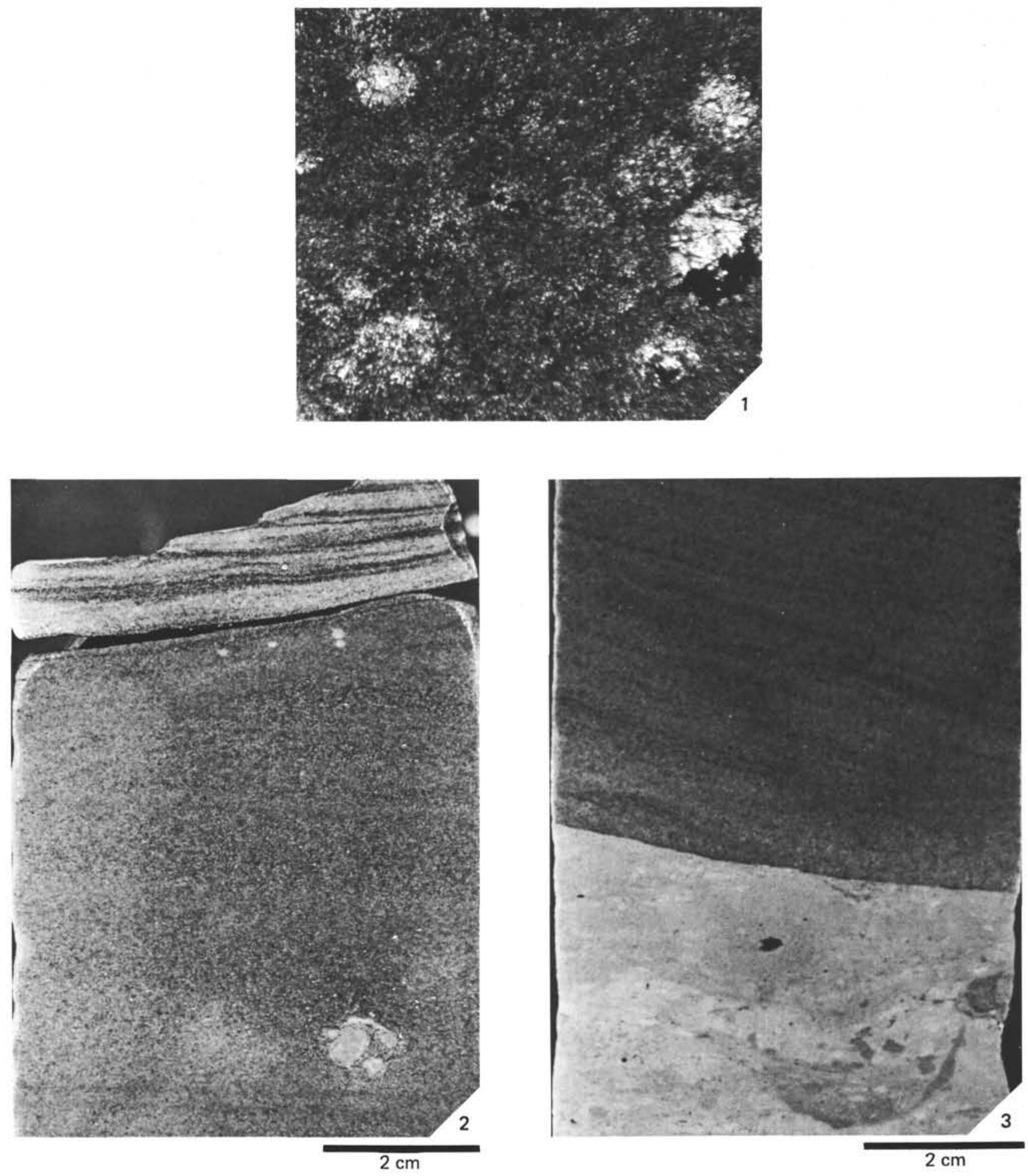
PLATE 2
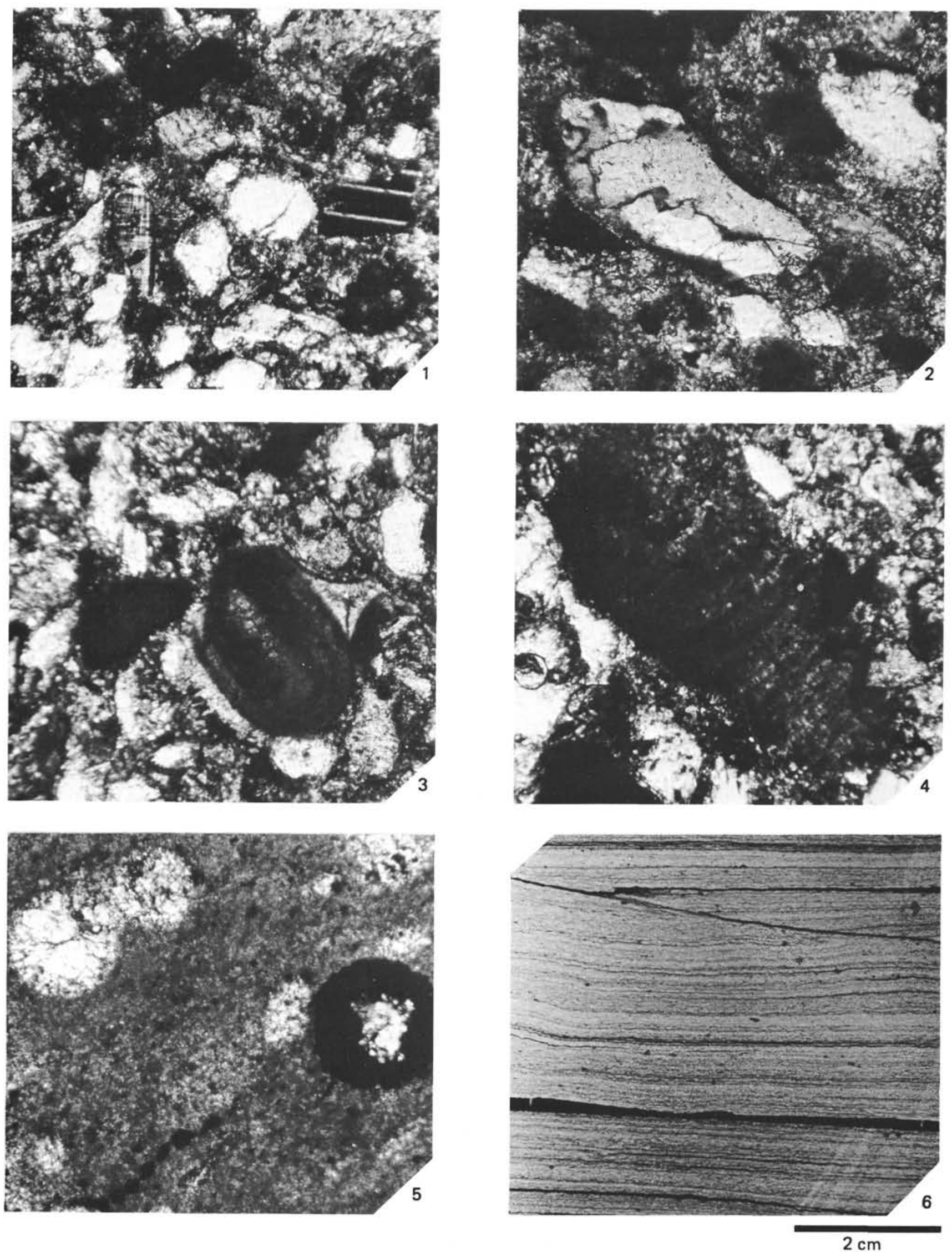


\section{PLATE 3}

Structures and Fossils From Sub-units $4 b$ and $4 c$

Figure 1

Core of calcareous claystone from sub-unit $4 b$ with distorted laminae reflecting dewatering events. Sample 391C-25-1, 72-84 cm.

Figure 2 Core of calcareous claystone from sub-unit $4 \mathrm{~b}$ with microfaults possibly produced by dewatering. Sample 391C-33-3, 127-136 cm.

Figure 3 Core of calcareous claystone from sub-unit $4 \mathrm{c}$ showing wispy discontinuous laminae. Sample $391 \mathrm{C}-36-5,73-82 \mathrm{~cm}$.

Figure 4 Photomicrograph (plane light) of Thaumatoporella from sub-unit 4 c. $\times 160$. Sample $391 \mathrm{C}-34-4$, $3-8 \mathrm{~cm}$.

(see p. 472)

\section{PLATE 4}

Structures From Sub-units 4d, 5a, and $4 \mathrm{~b}$

Figure $1 \quad$ Core of sub-unit $4 \mathrm{~d}$ with a Zoophycos burrow. Sample 391C-40, CC, 9-17 cm.

Figure 2

Core of sub-unit $4 \mathrm{~d}$ which shows the most shallow (1270 m sub-bottom) stylolites encountered at Site 391. Sample 391C-39-3, 109-120 cm.

Figure 3 Core of red marlstone from sub-unit 5a. Sample $391 \mathrm{C}-49-2,112-118 \mathrm{~cm}$.

Figure 4 Core of millimeter-laminated lime mudstone from sub-unit 4b. Sample 391C-31-2, 112-120 cm.

(see p. 473) 
PLATE 3
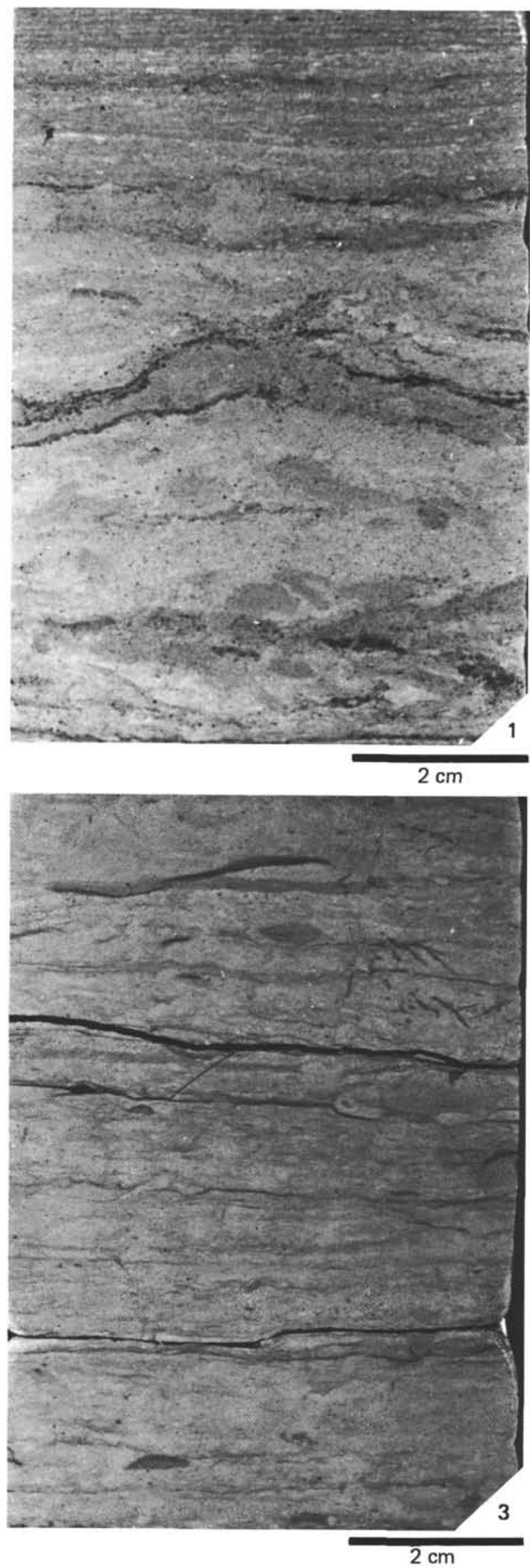

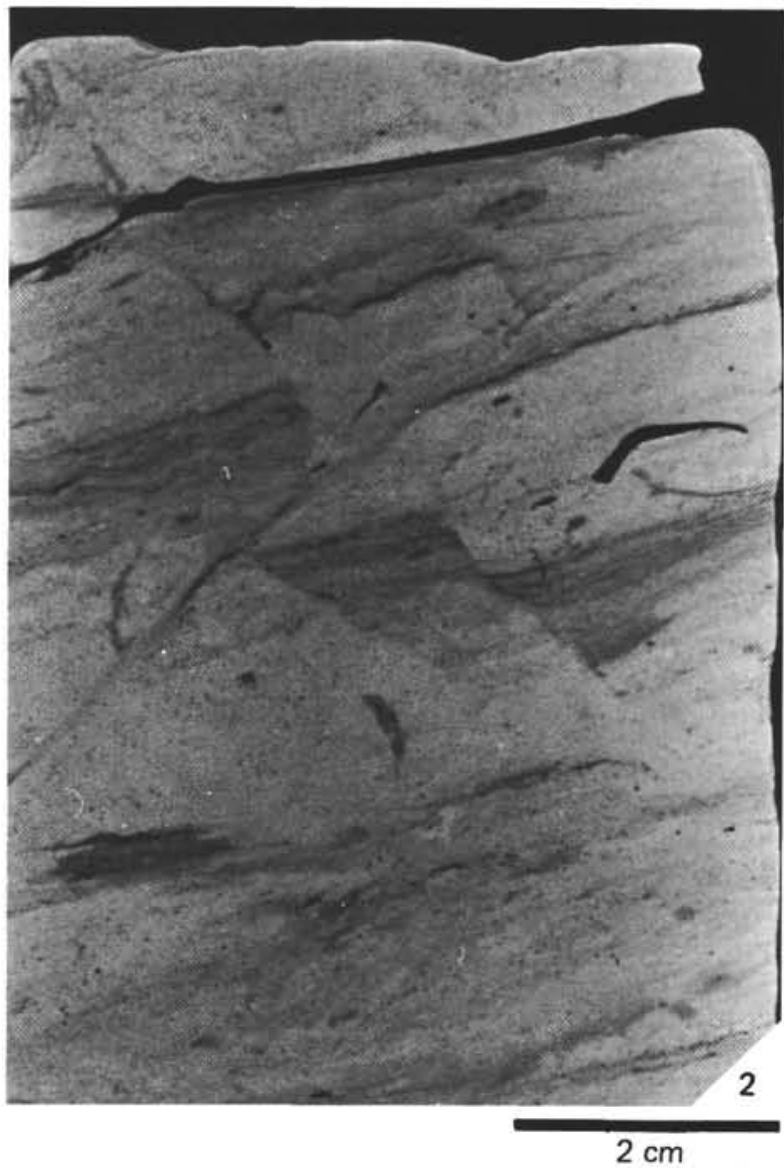

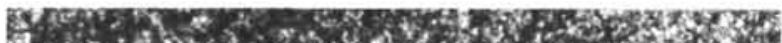

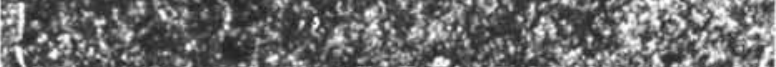

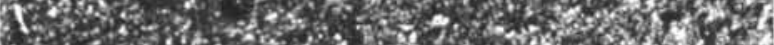

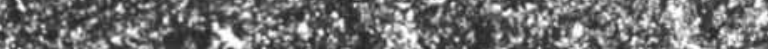

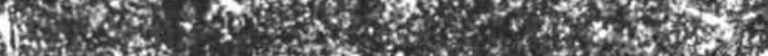

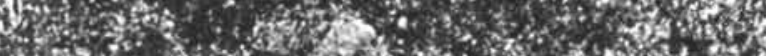

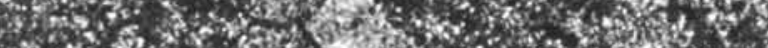

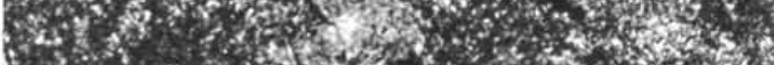

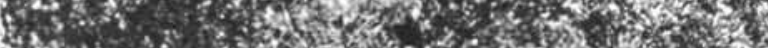

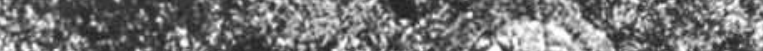

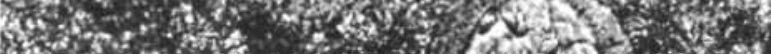

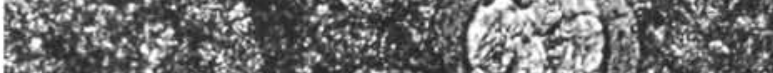

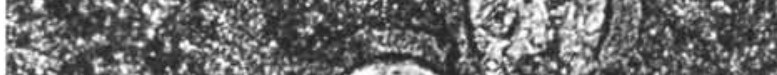

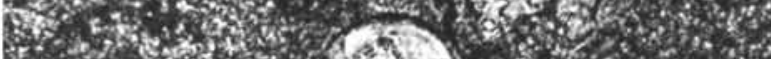

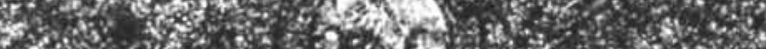

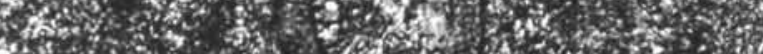

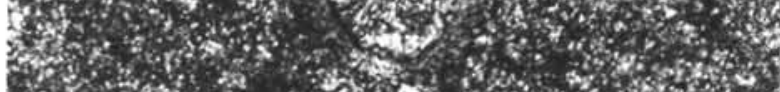

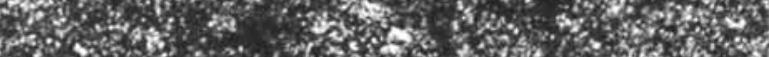

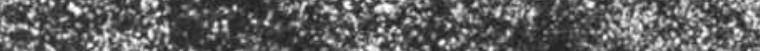

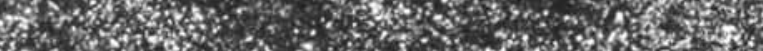

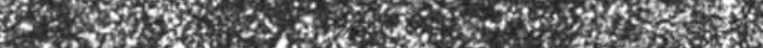

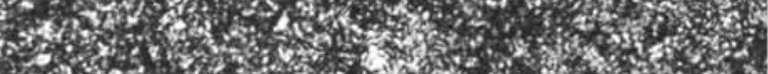

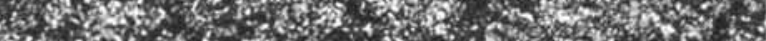
ser.

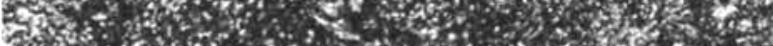

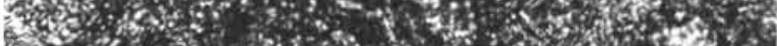

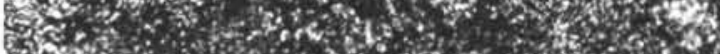

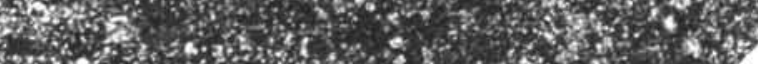

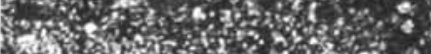

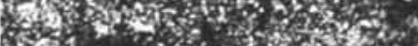

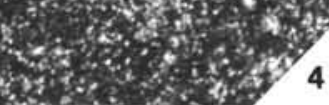


PLATE 4
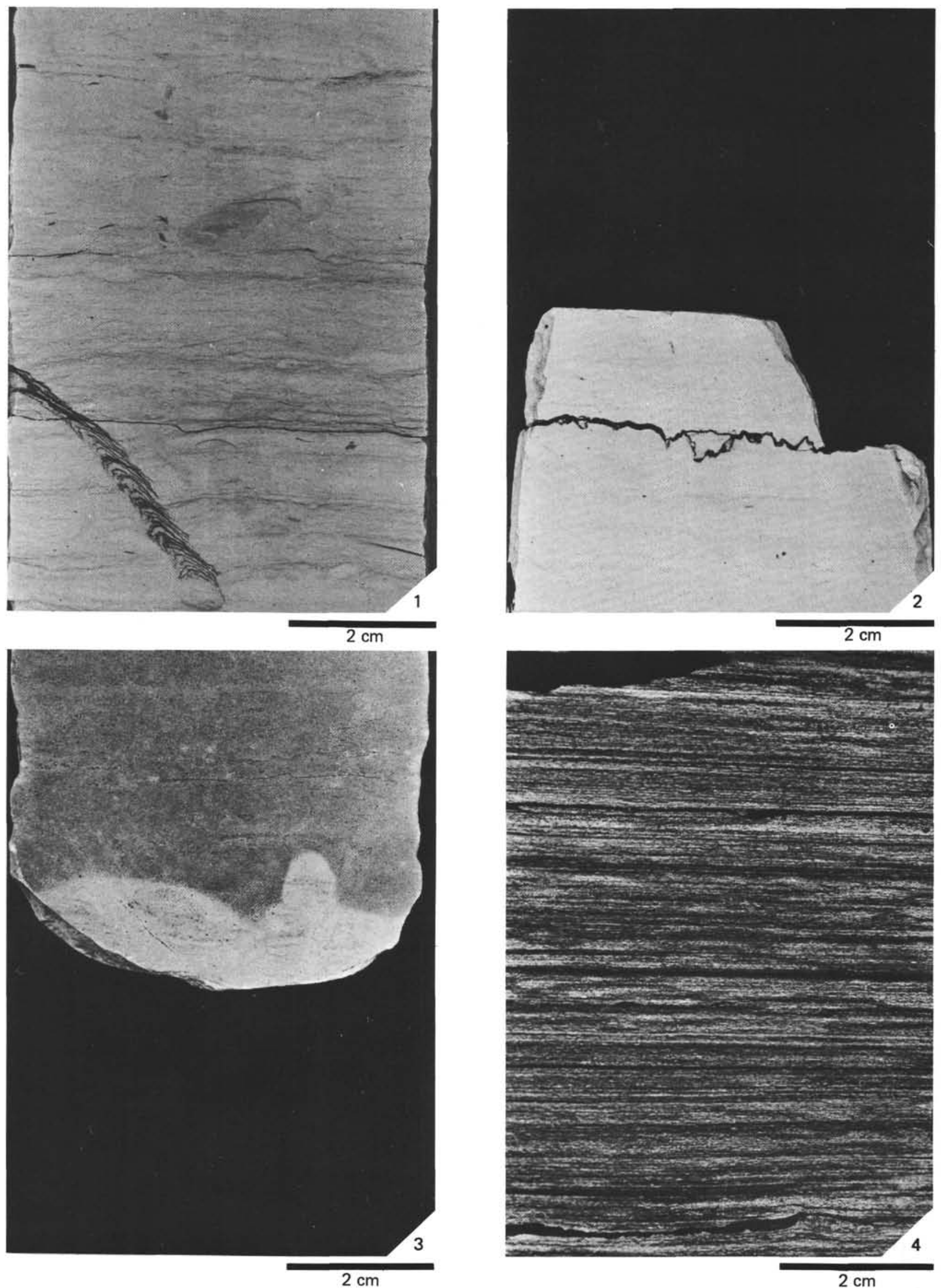


\section{PLATE 5}

Microfossils From Sub-units 4a, 4b, and 4d

Figure 1 Photomicrograph (plane light) of compacted (ellipsoidal) radiolarian molds in sub-unit $4 \mathrm{~b}$. $\times 55$. Sample 391C-24-5, 123-127 cm.

Figure 2 Photomicrograph (plane light) of sparry calcite cement within a radiolarian mold in sub-unit $4 \mathrm{~b}$. $\times 400$. Sample 391C-25-1, 72-84 cm.

Figure 3 Photomicrograph (plane light) of sparry calcite cement within a siliceous spicule in sub-unit $4 \mathrm{a}$. $\times 400$. Sample $391 \mathrm{C}-17-4,85-89 \mathrm{~cm}$.

Figure 4 Photomicrograph (plane light) of geopetal fillings within radiolarian molds of sub-unit $4 \mathrm{~b} . \times 160$. Sample 391C-24-2, 122-135 cm. In this case, calcite definitely replaced the radiolarian wall, rather than simply filling a radiolarian mold.

Figure 5 Photomicrograph (plane light) of calcitized and pyritized radiolarians from sub-unit $4 \mathrm{~b}$. $\times 55$. Sample 391C-33-3, 127-139 cm.

Figure 6 Photograph (plane light) of partially silicified (lower half) radiolarian lime mudstone, in sub-unit 4 d. $\times 55$. Sample $391 \mathrm{C}-38-2,50-56 \mathrm{~cm}$. 
PLATE 5
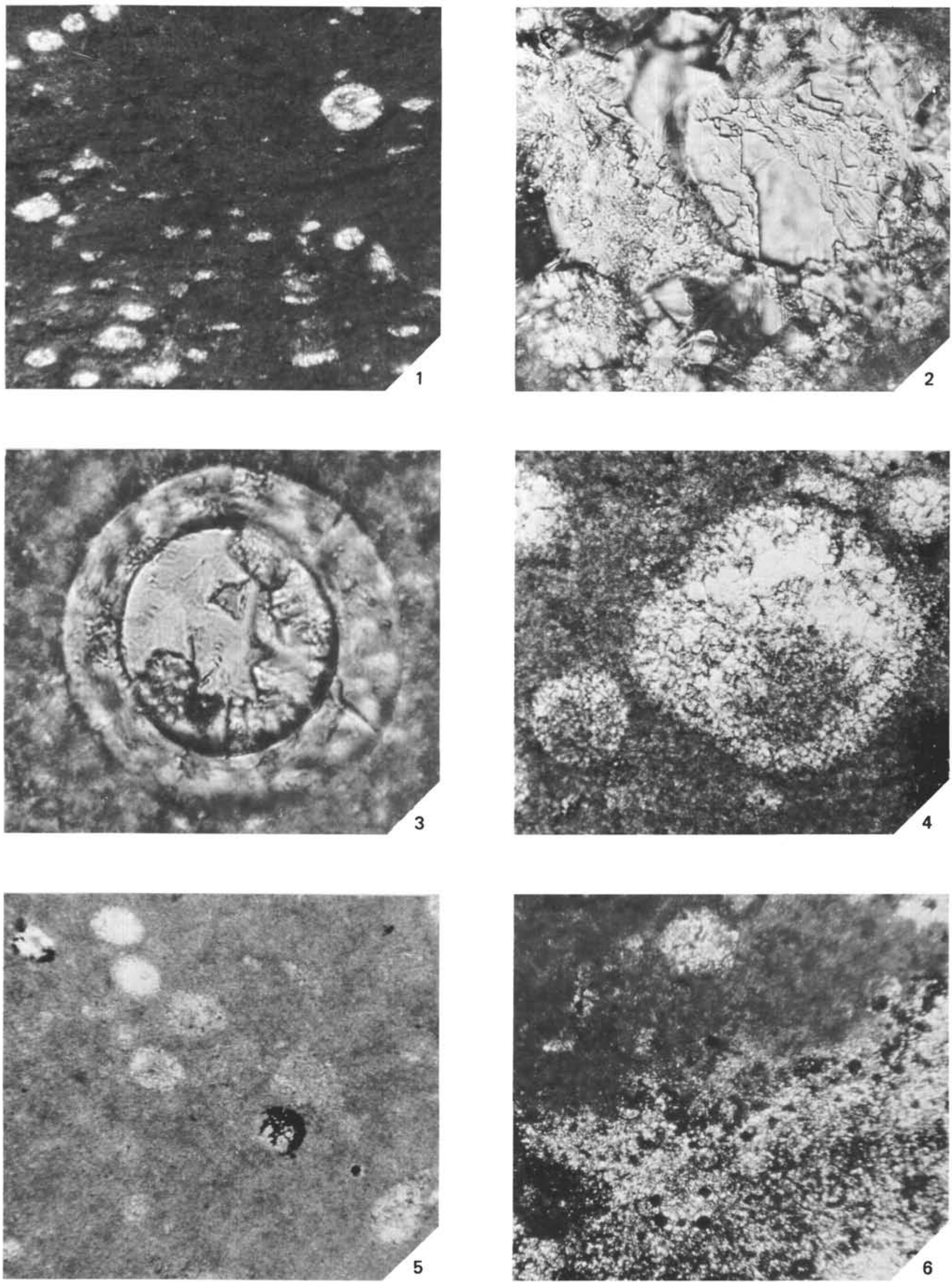